\title{
The applicability of the ECHR in contested territories
}

\author{
Marko Milanović* and Tatjana Papić**
}

\begin{abstract}
This article examines the applicability of the European Convention for Human Rights (ECHR) when a State loses control over parts of its territory. It argues that the jurisprudence of the European Court for Human Rights, which insists on residual positive obligations based in sovereign title over territory, is problematic and needs to be rethought. The Court's current approach is not only likely to provoke backlash, since it requires it to decide politically explosive questions of sovereign title, but does so for very little practical benefit for the protection of human rights. The article therefore explores more preferable alternatives.
\end{abstract}

Key words: jurisdiction, responsibility, ECHR, European Court of Human Rights, sovereignty, positive obligations, Kosovo, Georgia, Ukraine, Russia, Crimea.

\section{INTRODUCTION}

The world is replete with examples of contested territories, in which there is a dispute over sovereignty, or the title-bearing State is unable to exercise control over all of its territory consider only the hold that, until very recently, the Islamic State terrorist group had over vast swathes of Iraq and Syria. Such situations also exist in Europe and they have increasingly arisen 
in cases before the European Court of Human Rights (ECtHR). This article explores the applicability of the European Convention on Human Rights (ECHR) in contested territories, in light of the Court's case law. This topic has not attracted much attention in the academic literature, ${ }^{1}$ but its significance, politically and legally, is both manifest and is likely to be on the rise. For instance, the Court currently has on its docket an interstate case between Georgia and Russia, three interstate cases between Ukraine and Russia, and thousands of individual applications which concern either Crimea or Eastern Ukraine.

This article's main focus is on the threshold question of the ECHR's applicability, rather than on its substantive application - that is, we will be looking at whether the ECHR applies in contested territories, rather than at how its rights and obligations apply in specific factual contexts. However, although these two issues are conceptually distinct, as a matter of practical reality they are not; it is inevitable that potential substantive consequences influence legal and policy views on threshold questions. ${ }^{2}$ This article argues that the Court's jurisprudence on the ECHR's applicability in contested territories is evolving - which is a good thing, because that evolution is much needed - but that the overall direction of this evolution remains unclear. The article sets out the different options that the Court might take in this dynamic process, with their upsides and downsides.

Section 2 defines the scope of our inquiry, by setting out the basic framework of the Convention's territorial scope of application under Article 1 thereof, and by examining different types of contested territories. Section 3 provides an overview of Strasbourg jurisprudence in situations of loss of state control over parts of its territory. Section 4 evaluates the Court's approach and argues that it needs to be rethought. In particular, the idea of residual positive obligations grounded solely in sovereign title is conceptually unsound and normatively

\footnotetext{
* Professor of Public International Law, University of Nottingham School of Law; marko.milanovic@nottingham.ac.uk.

** Associate Professor, Union University Faculty of Law, Belgrade; tatjana.papic@pravnifakultet.rs.

1 A notable exception is K. Mujezinović Larsen, “Territorial Non-Application' of the European Convention on Human Rights' (2009) 78 Nordic Journal of International Law 73. See also (with a somewhat different focus) G Yudkivska, 'Territorial Jurisdiction and Positive Obligations of an Occupied State: Some Reflections on Evolving Issues Under Article 1 of the European Convention,' in A van Aaken and I Motoc (eds) The European Convention on Human Rights and General International Law (OUP, forthcoming), draft available on SSRN at https://ssrn.com/abstract=2825208 (all page citations are to this draft).

${ }^{2}$ See generally M Milanović, Extraterritorial Application of Human Rights Treaties: Law, Principles, and Policy (OUP 2011).
} 
unappealing. We argue that it should be abandoned in favour of better alternatives. Section 5 concludes.

\section{FRAMEWORK AND DEFINITIONS}

\section{A. Territorial applicability under Article 1 ECHR}

Pursuant to Article 1 ECHR, '[t]he High Contracting Parties shall secure to everyone within their jurisdiction the rights and freedoms defined in [the] Convention.' Obligations of State parties are thus triggered once a person is within a State party's jurisdiction, a concept which proved to be of key importance in the Court's jurisprudence and which, despite its deceptive simplicity, proved difficult to apply in practice. ${ }^{3}$ Jurisdiction became a threshold criterion that determines whether there is an international obligation for a State party under the ECHR vis-à-vis a given individual, which is a precondition for its international responsibility. Only when there is an international obligation for a state, may its breach lead to the state's international responsibility. ${ }^{4}$

The ECtHR has interpreted this threshold criterion of State jurisdiction to primarily have a territorial meaning, and at that one which should also be informed by the concept of jurisdiction in general international law. ${ }^{5}$ The Court's latter position is erroneous. It conflates the word 'jurisdiction' in Article 1 with the general international law concepts of State prescriptive and enforcement jurisdiction, which have a manifestly different purpose than Article 1, viz. the extension of a state's own domestic law to a certain situation, and the enforcement of that law, as it relates to the sovereignty of other states. ${ }^{6}$ The former point is however correct simply as a descriptive matter - the vast majority of the acts or relationships regulated by the ECHR will take place on the state's own territory. In that regard, there is an evidentiary presumption that a

\footnotetext{
${ }^{3}$ The ECtHR also relied on Article 1 in developing positive obligations under the Convention. See DJ Harris, M O'Boyle, EP Bates, CM Buckley, Harris, O'Boyle and Warbrick, Law of the European Convention on Human Rights (OUP 2014) 21.

${ }^{4}$ An internationally wrongful act of a state, which entails the international responsibility of that state, exists when an action or omission (a) is attributable to the state under international law; and (b) constitutes a breach of an international obligation of the state. See International Law Commission, Draft Articles on State Responsibility for Internationally Wrongful Acts, with commentaries, 2001, Official Records of the General Assembly, Fifty-sixth Session, Supplement No. 10, UN doc A/56/10, http://legal.un.org/ilc/texts/instruments/english/commentaries/9_6_2001.pdf, 20 July 2017 (ILC ASR), arts. 1 and 2. ${ }_{5}^{5}$ Banković et al. v Belgium et al. [GC], Application No 52207/99, Decision of 12 December 2001, paras 59-63; Al Skeini et al. $v$ the United Kingdom, Application No 55721/07, Judgment of 7 July 2011, para 131.

${ }^{6}$ See generally Milanović (n 2) 21-41.
} 
State has jurisdiction in the sense of Article 1 over all of its territory. ${ }^{7}$ However, as we will explain in more detail below, the Court also held that, in exceptional circumstances, this presumption could be rebutted or altered. ${ }^{8}$

In line with other human rights bodies, the Court has interpreted the word 'jurisdiction' in two basic ways. ${ }^{9}$ First, as a spatial concept - an individual is within a state's jurisdiction if they are located within a territory or area over which the State has effective overall control. Second, as a personal concept - an individual is within a state's jurisdiction if they were subject to the authority or control of a State agent. Both models of jurisdiction were reaffirmed in Al-Skeini, which remains the Court's leading case on Article $1 .{ }^{10}$ However, most leading Article 1 cases concern situations of the ECHR extraterritorial applicability, e.g. to the conduct of British troops in the occupation of Iraq, while our main concern here is the applicability of the Convention within a state's territory when the State has lost control over that territory.

\section{B. Position under general international law}

The general international law of treaties does not provide much guidance with regard to the application of treaties to parts of State territory outside its control. Article 29 of the Vienna Convention on the Law of Treaties provides that ' $[\mathrm{u}]$ nless a different intention appears from the treaty or is otherwise established, a treaty is binding upon each party in respect of its entire territory." ${ }^{11}$ The focus of this provision is, however, on treaty-making by states which have territorial sub-units with a significant degree of political autonomy. In the context of federal or non-unitary states federal clauses can permit a state's units to be exempt from the scope of the treaty or limit obligations of the federal/non-unitary State in the matters that are outside of its constitutional power. ${ }^{12}$ There is no such clause in the ECHR. ${ }^{13}$ The Convention does however

\footnotetext{
${ }^{7}$ See Assanidze v Georgia, Application No 71503/01, Judgment of 8 April 2004, para 139; Ilaşcu et al. v Moldova and Russia, Application No 48787/99, Judgment of 8 July 2004, para 312.

${ }^{8}$ See Assanidze, para 139; Ilaşcu, para 312.

9 See generally Milanović, (n 2); UN Human Rights Committee, General Comment No 31, UN Doc CCPR/C/21/Rev.1/Add.13 (2004), para 10. ICJ, Legal Consequences of the Construction of a Wall in the Occupied Palestinian Territory (Advisory Opinion) [2004] ICJ Rep 136, 179, para 109.

${ }^{10}$ Al-Skeini, paras 133-140.

11 Art. 29 Vienna Convention on the Law of Treaties, UNTS, vol. 1155, 331. See more S. Karagiannis, 'The Territorial Application of Treaties,' in D.B. Hollis (ed.), The Oxford Guide to Treaties (OUP 2012) 305.

${ }^{12}$ ILC ASR (n 4), 42, para 10, A. Aust, "Treaties, Territorial Application", Max Planck Encyclopedia of Public International Law, Max Planck Institute for Comparative Public Law and International Law/Heidelberg and OUP, Heidelberg and Oxford 2012, 5, para 22.

${ }^{13}$ There is one in Art 28 of the American Convention on Human Rights. UNTS, vol. 1144, 123.
} 
have a colonial clause, which performs similar functions for (overseas) territories for whose international relations a State is responsible, and which is of no relevance to us here. ${ }^{14}$

The issue of the Convention's applicability to contested territories is thus not determined by rules of general international law, but by the interpretation of the Convention itself, especially its Article 1. In that regard, the Court has in its case law precluded one option for varying the Convention's territorial scope - reservations - by ruling that a State could not make a valid reservation to the ECHR pursuant to its Article 57 the effect of which would be a territorial limitation on obligations. ${ }^{15}$ Thus, when a non-unitary/federal State faces challenges in securing ECHR's rights and freedoms within its territorial units and autonomous regions simply due to its internal constitutional arrangements, this will not influence the scope of its obligations under the ECHR, as was held in Assanidze v. Georgia. ${ }^{16}$ In that case, Georgia was responsible for the violations of the ECHR due to the conduct of the authorities of the Ajarian Autonomous Republic (AAR), an integral part of Georgia enjoying a high level of autonomy. Namely, the applicant remained in prison in the AAR despite the fact that the Supreme Court of Georgia discontinued the criminal proceedings and ordered his immediate release. The fact that the AAR authorities failed to implement this decision did not affect Georgia's international responsibility, which extended to the conduct of the AAR. ${ }^{17}$

\section{Defining contested territories}

The term 'contested territories' that we are employing here is not a legal term of art, but is useful shorthand for several different types of situations which entail the loss of territorial control, and which we will now elaborate on. First, we can distinguish between territorial contestation that is primarily internal, i.e. coming from within the relevant State, and contestation which is primarily external, i.e. involves another State.

In the first scenario, the State loses control over a part of its territory due to its inability to suppress the activities of a non-state actor in the area, provide basic public functions and

\footnotetext{
${ }^{14}$ See Art. 56 ECHR; see more L. Moor, B. Simpson, 'Ghosts of Colonialism in the European Convention on Human Rights’ (2005) 76 British Yearbook of International Law 121.

${ }^{15}$ See Assanizde, para 140; Sargsyan v Azerbaijan [GC], Application No 40167/06, Decision of 16 June 2015, paras 63-70, 93.

${ }_{16}^{16}$ Assanidze, para 141.

${ }^{17}$ ibid para 56.
} 
maintain its monopoly on the use of force. On one end of the spectrum, we can have situations of State failure in which the area concerned degenerates into a chaotic 'ungoverned space' consider, for instance, the difficulties that Mexico or Colombia have faced over the years with suppressing the activities of drug cartels on their territories. On the other, the relevant non-state actor can be highly organized and exhibit quasi- or parastatal qualities. Such entities may be openly separatist and may even formally claim independence from the parent State - consider, for example, the Turkish Republic of Northern Cyprus vis-à-vis Cyprus; Kosovo vis-à-vis Serbia; or South Ossetia and Abkhazia vis-à-vis Georgia.

In the second scenario, a third State wrests control of an area from the territorial sovereign. The clearest such example today would be Crimea, which Russia formally (if clearly unlawfully) annexed from Ukraine. More common would be situations in which the third State does not claim sovereignty over the area which it took control of - for example, Russia's control over parts of Georgia proper during the 2008 Georgia/Russia conflict, or, outside Europe, the UK's control over parts of Iraq and Afghanistan during the conflicts there. In all of these situations the territorial State loses control over some or even all of its territory due to outside intervention.

The two scenarios set out above may overlap. This is the case in situations in which a third State intervenes in the territorial State by way of a proxy non-state actor. The issue in such cases is whether the third State controls the area concerned through its own armed forces and other organs and agents, as has been the case with Turkey's control over Northern Cyprus, or whether the third State controls the non-state actor itself, whether pursuant to the general rules of attribution in the law of state responsibility ${ }^{18}$ or, perhaps, some ECHR-specific rules of attribution. ${ }^{19}$ Consider, for example, the relationship between Russia and the Donetsk and

\footnotetext{
${ }^{18}$ Most relevant here would be attribution due to de facto organ status arising from a relationship of complete dependence and control between the intervening State and the proxy non-state actor, which attributes all of the conduct of the non-state actor to the State concerned pursuant to the rule in Art. 4 ILC ASR, and attribution based on the State instructions or effective control over the specific conduct of the non-state actor, under Art. 8 ILC ASR. See generally J. Crawford, State Responsibility: The General Part (CUP 2013) 124-126, 146-156.

19 The Court has never been clear on whether it is (exceptionally) applying ECHR-specific rules of attribution (which would be regarded as lex specialis under Art. 55 ILC ASR), but some of its cases could easily be so interpreted - see, e.g., Cyprus v Turkey, Application No 25781/94, Judgment of 10 May 2001, para 77 ('[Turkey's] responsibility cannot be confined to the acts of its own soldiers or officials in northern Cyprus but must also be engaged by virtue of the acts of the local administration which survives by virtue of Turkish military and other support.' - 'survival' is similar, but not necessarily the same, as the complete dependence test in general international law); para. 81 ('the acquiescence or connivance of the authorities of a Contracting State in the acts of
} 
Luhansk rebels in the Donbas in Eastern Ukraine, or Russia's relationship with South Ossetia and Abkhazia in Georgia. Clearly, as far as any litigation before the ECtHR is concerned, the key question here would be what evidence exists as to the exact nature of this relationship, i.e. whether the non-state group is merely being supported by the intervening State or is in fact that state's proxy.

When there is a sovereignty dispute over a territory between two states parties to the ECHR, one likely consequence of the competing sovereignty claims is that the states concerned will not tend to deny the ECHR's applicability to the territory. For example, Russia will not contest the ECHR's applicability to its own conduct in Crimea after the annexation, because doing so would be incongruent with its own claim to sovereignty over the area. A shift in territorial control would thus, at least in principle, not result in a total vacuum of human rights protection for the population of the area concerned. Scenarios in which the competing sovereignty claim is raised by a separatist entity whose claim to statehood is not undisputed, as is for instance the case with Kosovo and Serbia (or potentially with Catalonia and Spain), are more difficult. If the entity in question is unable to obtain a sufficient measure of recognition and membership in the Council of Europe, it will not be able to become a party to the ECHR and a protection vacuum becomes more likely. ${ }^{20}$

In short, in determining the nature of a contested territory we can ask the following questions: is there an entity which has supplanted the territorial sovereign in its control over the area concerned, and what kind of an entity is it? Is it (1) a simple non-state armed group; (2) a highly organized, parastatal non-state actor; (3) a highly organized non-state actor claiming independent statehood; (4) a non-state actor which is a proxy of a third, intervening State; (5) the organs and agents of a third State acting directly, claiming (or not) sovereignty over the contested area. To these questions we can add a further, temporal one - how long has the situation of contestation lasted, or is likely to last? We can thus observe how territorial

private individuals which violate the Convention rights of other individuals within its jurisdiction may engage that State's responsibility under the Convention.' - again, not an approach easily squared with the ILC ASR). These tests have been reaffirmed in multiple subsequent judgments, but again it is not clear whether the Court thinks it is applying (correctly or not) a general international law attribution framework or a Convention-specific one. See, e.g., Sindicatul "Păstorul cel Bun" v. Romania [GC], Application No 2330/09, Judgment of 9 July 2013, para 76; ElMasri v. the former Yugoslav Republic of Macedonia [GC], Application No 39630/09, Judgment of 13 December 2012, paras $206 \& 211$.

${ }^{20}$ See more part III.D below. 
contestation can be acute or short-term on the one hand, or chronic, stable and long-term on the other. The territorial sovereign's loss of control over a part of its territory could be very shortlived, lasting a few days or weeks, or it could be prolonged, lasting many years or even decades. For example, Georgia lost control of the city of Gori to Russian forces for some 10 days in August 2008, but its loss of control over (most of) South Ossetia and Abkhazia dates to the mid 1990s, and it is not likely to regain control in the foreseeable future. Cyprus has not been in control over the northern part of the island since 1974. Ukraine is similarly not likely to regain control over Crimea anytime soon, if ever.

Bearing in mind these different situations of territorial contestations, let us turn to an examination of the ECtHR's relevant case law.

\section{OVERVIEW OF STRASBOURG JURISPRUDENCE ON THE LOSS OF TERRITORIAL CONTROL}

\section{A. Initial approach: the presumption of jurisdiction and its rebuttal}

The initial approach of the European Commission to situations of loss of a state's control over its territory was simple: there was a presumption that the State had control over all of the territory to which it had title, but that presumption was rebuttable on the facts. If it was indeed rebutted, the territorial State no longer had obligations under the ECHR, as it no longer had jurisdiction in the sense of Article 1 over the area concerned. The first such cases were those on northern Cyprus. In 1974, the separatist Turkish Republic of Northern Cyprus (TRNC) was established through the use of regular Turkish armed forces. The presumption of Cyprus' jurisdiction was rebutted either expressly, ${ }^{21}$ or by implication, in cases against Turkey, which was held to have extraterritorial jurisdiction in northern Cyprus and consequently obligations under the ECHR. ${ }^{22}$

\footnotetext{
${ }^{21}$ See e.g. ECmHR, Cyprus v Turkey, Application No 8007/77, Decision of 10 July 1978, paras 23-24.

${ }^{22}$ Cyprus v Turkey, Application No 25781/94, Judgment of 10 May 2001, paras 77-78. The ECtHR held that in such circumstances a different finding from the one that they were within jurisdiction of Turkey would leave applicants in a "regrettable vacuum in the system of human rights protection." ibid para 78. The reference to a vacuum is an indirect assessment that Cyprus no longer exercised jurisdiction over the area.
} 
In a single case brought against Cyprus for violations of the ECHR in the north, the Commission declared the application inadmissible due to its incompatibility with Article 1 ECHR: ${ }^{23}$

The Commission has previously observed that "the European Convention on Human Rights continues to apply to the whole of the territory of the Republic of Cyprus" and that the recognition by Turkey of the Turkish Cypriot administration in the north of Cyprus as "Turkish Federated State of Cyprus" does not affect "the continuing existence of the Republic of Cyprus as a single State and High Contracting Party to the Convention" (No. 8007/77, Cyprus v. Turkey, Dec. 10.7.78, D.R. 13, p. 85 at pp. 149-150).

At the same time, however, the Commission has also found that the Government of the Republic of Cyprus "have since 1974 been prevented from exercising their jurisdiction in the north of the island. This restriction on the actual exercise of jurisdiction ... is due to the presence of Turkish armed forces" (ibid.).

The Commission now finds that the authority of the respondent Government is in fact still limited to the southern part of Cyprus. It follows that the Republic of Cyprus cannot be held responsible under Article 1 (Art. 1) of the Convention for the acts of Turkish Cypriot authorities in the north of Cyprus of which the present applicants complain. ${ }^{24}$

The Commission's reference to Cyprus' lack of responsibility for the acts of Turkish Cypriot authorities could be interpreted as the application of an attribution test. In context, however, it is clear that the Commission was thinking in terms of lack of obligation on the part of Cyprus, due to its lack of actual jurisdiction in the north. Note also how the Commission did not hesitate to expressly affirm Cyprus' continued sovereignty over the contested territory. In its 1996 Loizidou judgment the Court likewise recalled the rejection of the TRNC's claim to statehood by the United Nations (UN) Security Council and European institutions, stating that 'the international community does not regard the "TRNC" as a State under international law and that the Republic of Cyprus has remained the sole legitimate Government of Cyprus - itself, bound to respect international standards in the field of the protection of human and minority rights. ${ }^{25}$ The Court did not however remark on the scope of Cyprus' obligation due to its lack of territorial control, as it was not called upon to do so.

\footnotetext{
${ }^{23}$ ECmHR, An and Others v Cyprus, Application No 18270/91, Decision of 18 October 1991.

24 ibid

${ }^{25}$ Loizidou v Turkey (merits), Application No 15318/89, Judgment of 18 December 1996, para 44.
} 
The Court followed the Commission's presumption/rebuttal approach in its 2004 Assanidze judgment, as noted above. Importantly, Georgia did not dispute that the applicant was within its jurisdiction, but the ECtHR nevertheless went on to discuss whether there was valid evidence of the AAR's separatist ambitions or effective control of another State to rebut the presumption of jurisdiction, ${ }^{26}$ and found there was none. ${ }^{27}$ Only a few months later, however, the Court did something very different in Ilaşcu et al. v. Moldova and Russia.

\section{B. Ilaşcu and Catan: jurisdiction attenuated, but not removed}

In Ilaşcu the ECtHR had to decide on the responsibility of Moldova and Russia for the illegal arrest, detention and ill-treatment of four Moldovan nationals in Transdniestria, in the east of Moldova, ${ }^{28}$ where the separatist "Moldavian Republic of Transdniestria" (MRT) was proclaimed. ${ }^{29}$ Moldova did not have effective control over the area, ${ }^{30}$ while Russia - unlike Turkey in the Northern Cyprus - did not occupy Transdniestria but contributed to the creation of the MRT, and provided political, economic and military support to it. ${ }^{31}$ Because of this, even after violent clashes between Transdniestrian separatist forces and the Moldovan security forces (end of 1991-beginning of 1992), ${ }^{32}$ Moldova did not regain control over this part of its territory. ${ }^{33}$ It subsequently made political efforts to re-establish control over Transdniestria; as of mid-1992 it adopted an acquiescent attitude towards the situation in Transdniestria, ${ }^{34}$ maintained a limited control over the issue of identity cards and customs stamps and had „more or less de facto relations" with Transdniestrian authorities in some fields. ${ }^{35}$

In Ilaşcu, the ECtHR's starting point was that the presumption of a state's jurisdiction may be limited [only] in exceptional circumstances, particularly where a State is prevented from exercising its authority in part of its territory. That may be as a result of military occupation by the armed forces of another State which effectively controls the

\footnotetext{
${ }^{26}$ Assanidze, paras 133 and 134.

27 ibid paras 139-143.

${ }^{28}$ Ilaşcu, para 331.

${ }^{29}$ ibid. This entity was not internationally recognized. ibid para 2.

${ }^{30}$ ibid para 331.

31 ibid paras 382, 392.

32 ibid para 51 .

33 ibid para 65.

34 ibid para 329.

35 ibid paras $179-180$.
} 
territory concerned [...], acts of war or rebellion, or the acts of a foreign State supporting the installation of a separatist State within the territory of the State concerned. ${ }^{36}$

Note the reference to a limitation rather than a rebuttal of jurisdiction. The Court then held that Moldova did not exercise authority over part of its territory, which was under the effective control of the MRT, ${ }^{37}$ but nevertheless found that it still had positive obligations under Article lin order to secure ECHR rights. ${ }^{38}$ These residual positive obligations are twofold, including measures (1) aimed at re-establishing its control over the territory in question, and (2) securing the applicants' individual rights. ${ }^{39}$ Hence, the factual situation in the Transdniestrian region did not mean that Moldova ceased to have jurisdiction, and thus obligations, under the ECHR. Rather, its jurisdiction was reduced in scope to certain specified positive obligations:

On the basis of all the material in its possession, the Court considers that the Moldovan Government, the only legitimate government of the Republic of Moldova under international law, does not exercise authority over part of its territory, namely that part which is under the effective control of the "MRT". ... However, even in the absence of effective control over the Transdniestrian region, Moldova still has a positive obligation under Article 1 of the Convention to take the diplomatic, economic, judicial or other measures that it is in its power to take and are in accordance with international law to secure to the applicants the rights guaranteed by the Convention. ${ }^{40}$

The ECtHR thus held that Moldova violated these obligations because after 2001 it failed to discuss the applicants' case in the negotiations for a settlement of the situation in Transdniestria, and failed to consider or take any other steps to secure to the applicants their ECHR rights. ${ }^{41}$

The holding of the ECtHR in this case was innovative for several reasons. First, jurisdiction was not discussed in terms of a presumption and its rebuttal, as before. The previous position was both less flexible and more in line with the wording of Article 1 - a State either had jurisdiction or it did not. There was no room for reductions, or for 'dividing and tailoring, ${ }^{42}$ to allow for a different scope of obligations depending on the exceptional circumstances of a case. ${ }^{43}$

\footnotetext{
36 ibid para 312. Emphasis added.

37 ibid para 330.

38 ibid paras 331-333.

39 ibid paras 339, 340-346.

40 ibid paras 333-334. Emphasis added.

41 ibid para 350.

42 This expression was used in the context of extraterritorial application. Cf. Banković, para 75 and Al-Skeini, para 137.

${ }^{43}$ See also Mujezinović Larsen (n 1) 86.
} 
Nor did, again, the wording of Article 1 provide support for the Ilaşcu residual positive obligations. Second, the notion of positive obligations was never given such an independent existence up to this point. Unlike in previous case law - where it was developed to ensure effective protection of a specific substantive right by requiring a State not only to refrain from violation but also to take steps to secure it ${ }^{44}$ - in Ilaşcu positive obligations were invoked in respect to the ECHR as whole. ${ }^{45}$ Finally, the ECtHR also considered applicants to concurrently be within the jurisdiction of Russia. ${ }^{46}$ Russia's jurisdiction was extraterritorial, ${ }^{47}$ and existed because the MRT remained 'under [its] effective authority, or at the very least under [its] decisive influence. ${ }^{48}$ In such circumstances, Russia needed to secure the entire set of substantive rights provided in the ECHR. ${ }^{49}$

The Court affirmed its Ilaşcu approach in Catan, a subsequent case dealing with violations of the right to education in Transdniestria: ${ }^{50}$

[I]n the Ilaşcu judgment, cited above, the Court held that individuals detained in Transdniestria fell within Moldova's jurisdiction because Moldova was the territorial State, even though it did not have effective control over the Transdniestrian region. Moldova's obligation under Article 1 of the Convention, to "secure to everyone within their jurisdiction the [Convention] rights and freedoms", was, however, limited in the circumstances to a positive obligation to take the diplomatic, economic, judicial or other measures that were both in its power to take and in accordance with international law ... The Court sees no ground on which to distinguish the present case. Although Moldova has no effective control over the acts of the "MRT" in Transdniestria, the fact that the region is recognised under public international law as part of Moldova's territory gives rise to an obligation, under Article 1 of the Convention, to use all legal and diplomatic means available to it to continue to guarantee the enjoyment of the rights and freedoms defined in the Convention to those living there. ${ }^{51}$

On the facts, however, and unlike in Ilaşcu, the Court found that Moldova had indeed satisfied its positive obligations. ${ }^{52}$ It also found that Russia continued to exercise jurisdiction

\footnotetext{
44 See Harris et al. (n 3) 21-23. See also A.R. Mowbray, The Development of Positive Obligations Under the European Convention on Human Rights by the European Court of Human Rights (Hart Publishing 2004).

${ }^{45}$ See more Mujezinović Larsen (n 1) 86.

46 Ilaşcu, para 394.

47 ibid paras 314-316.

48 ibid para 392.

${ }^{49}$ See also Cyprus v Turkey, paras 76-77.

${ }^{50}$ Catan and Others $v$ Moldova and Russia, Application Nos 43370/04, 8252/05 and 18454/06, Judgment of 19 October 2012.

51 ibid para 110 .

52 ibid paras 145-148.
} 
over the separatist entity in Transdniestria, despite Russia's somewhat diminished presence on the ground in the intervening years. ${ }^{53}$ On the merits, however, the Court was again not sufficiently precise in distinguishing between issues of jurisdiction and attribution of conduct. It is not clear from the judgment whether the Court is finding Russia responsible for the acts of separatist authorities because these are attributable to Russia, or because Russia failed to comply with a positive obligation to prevent such violations by a non-state actor operating within an area under its jurisdiction. ${ }^{54}$

In sum, in both Ilaşcu and Catan we can observe how Russia's plenary jurisdiction over Transdniestria offset Moldova's limited jurisdiction for fulfilling only positive obligations. ${ }^{55}$ In its most recent jurisprudence on the issue, the ECtHR was explicit in this respect: a limited jurisdiction of the territorial State was compensated by another ECHR State party's jurisdiction arising fully and extraterritorially. ${ }^{56}$ Conversely, however, the Court did not seem prepared to tolerate a vacuum - if there is no other State exercising extraterritorial jurisdiction over the area concern, the territorial state's jurisdiction would remain intact, without an Ilascu-type reduction. This will be discussed in the next section.

\section{Sargsyan: jurisdiction undiminished}

The case of Sargsyan v. Azerbaijan arose in the aftermath of the Nagorno-Karabakh conflict between Armenia and Azerbaijan. The applicants were denied return to their village, situated in the territory of Azerbaijan, but close to or on the line of contact between this State and the selfproclaimed Nagorno-Karabakh Republic. The village was destroyed, mined and remained inaccessible to any civilian. ${ }^{57}$

Azerbaijan argued that a concept developed in Ilasçu - a limited responsibility of a State in the case it lost effective control over part of its territory to another State or separatist regime should equally be applied to disputed zones or 'areas which are rendered inaccessible by the circumstances. ${ }^{58}$ However, the ECtHR did not accept this argument. ${ }^{59}$ Starting from the special

\footnotetext{
53 ibid paras 121-123.

54 See more M Milanović, 'Grand Chamber Judgment in Catan and Others' (EJIL: Talk!, 21 October 2012)

$<$ https://www.ejiltalk.org/grand-chamber-judgment-in-catan-and-others/>.

${ }^{55}$ See also Mujezinović Larsen (n 1) 84.

${ }^{56}$ Sargsyan, para 148.

57 ibid paras 47-49.

58 ibid paras 145-146.
} 
nature of the ECHR - 'a constitutional instrument of European public order (ordre public) for the protection of individual human beings ${ }^{60}$ - the Court emphasized that the whole territory of Azerbaijan entered the 'Convention legal space' upon its ratification of the ECHR. ${ }^{61}$ Then it proceeded to distinguish Sargsyan from Ilasçu and similar cases, ${ }^{62}$ on the basis that the area (village) in the former case was not occupied by the armed forces of another State, in the sense of the international law of belligerent occupation, ${ }^{63}$ and was not under the control of any separatist regime. Finally, the ECtHR used the same argument as the one used for establishing extraterritorial jurisdiction of Turkey in the case of the Northern Cyprus ${ }^{64}$ - a need to avoid the ECHR protection vacuum ${ }^{65}$ - to conclude there were no 'exceptional circumstances of such a nature as to qualify [Azerbaijan's] responsibility under the Convention. ${ }^{66}$

Not only did the ECtHR hold that the exception developed in Ilasçu was not applicable in this case, but it compared the situation in Sargsyan to the situation in Assanidze (dealing with application of the ECHR to a state's territorial units), stating that 'from a legal point of view the Government of Azerbaijan has jurisdiction as the territorial State and full responsibility under the Convention. ${ }^{67}$

In sum, in Sargsyan the Court was not prepared to accept pockets of vacuum in protection that resulted from Azerbaijan's willingness to maintain a no-man's land on its line of contact with Nagorno-Karabakh. On the merits the Court did take security issues into account, finding the ethnic Armenians displaced from the village concerned did not (as of yet) have the entitlement to return to the area which was still subject to ongoing military activity, but that Azerbaijan had to provide the applicants with alternative measures to secure their property rights (which it did not). ${ }^{68}$ And again, the approach of both the ECtHR and Azerbaijan manifested a

\footnotetext{
${ }^{59}$ ibid para 149.

${ }^{60}$ ibid para 147.

${ }^{61}$ ibid.

${ }^{62}$ Ivanţoc et al. v Moldova and Russia, Application No 23687/05, Judgment of 15 November 2011, para 105; Catan, para 109; Sargsyan, paras 140-142.

${ }^{63}$ ibid para 144. See more M Milanović, 'European Court Decides that Israel Is Not Occupying Gaza' (EJIL: Talk!, 17 June 2015) <https://www.ejiltalk.org/european-court-decides-that-israel-is-not-occupying-gaza>

${ }^{64} \mathrm{n} 22$.

${ }^{65}$ Sargsyan, para 148.

${ }^{66}$ ibid.

${ }^{67}$ ibid para 150 .

${ }^{68}$ ibid paras 233-242
} 
long standing confusion between jurisdiction and responsibility ${ }^{69}$ in the case-law of the ECtHR. ${ }^{70}$ Azerbaijan argued it had 'limited responsibility' due to exceptional circumstances, not that it had limited jurisdiction. The ECtHR accepted this framing, which is conceptually confusing, since the term jurisdiction is the basis of a threshold for the existence of legal obligations, while responsibility is the consequence of a breach of such obligations which are attributable to the state. $^{71}$ This conceptual confusion was even more evident in Chiragov, ${ }^{72}$ the companion case decided on the same day as Sargsyan, in which the Court found that Armenia exercised jurisdiction over Nagorno-Karabakh. The Court did so without specifying which wrongful conduct precisely was attributable to Armenia, in effect failing to distinguish between Armenia's control over the territory concerned and its control (or lack thereof) over the separatist entity in Nagorno-Karabakh as an actor. ${ }^{73}$

This brings us to how the Court dealt with the situation of Serbia and Kosovo, which presents a unique factual pattern - that of a territory initially subjected to an international administration which then declared independence from its parent state, while attracting a substantial, but far from uncontested, level of international recognition. ${ }^{74}$

\section{Serbia and Kosovo: avoiding sovereignty, accepting a vacuum}

After the 1999 NATO intervention, Kosovo, a province of Serbia (then part of the Federal Republic of Yugoslavia (FRY)), became a UN-administered territory on the basis of UN Security Council resolution 1244 (1999). ${ }^{75}$ After the establishment of the international administration and

\footnotetext{
${ }^{69}$ See, e.g., Cyprus v Turkey, para 78. See more Milanović supra note 2, at 41.

${ }^{70}$ See also Sargsyan, concurring opinion of judge Ziemele, para 3.

${ }^{71}$ See also M Milanović, 'Jurisdiction, Attribution and Responsibility in Jaloud' (EJIL: Talk!, 11 December 2014) $<$ https://www.ejiltalk.org/jurisdiction-attribution-and-responsibility-in-jaloud/>.

72 Chiragov and Others $v$ Armenia, Application No 13216/05, Judgment of 16 June 2015.

${ }^{73}$ See more M Milanović, 'The Nagorno-Karabakh Cases’ (EJIL: Talk! 23 June 2015) <https://www.ejiltalk.org/thenagorno-karabakh-cases/>.

${ }^{74}$ See more T Papić, 'Fighting for a Seat at the Table: International Representation of Kosovo' (2013) 12 Chinese Journal of International Law 543.

75 This resolution was preceded by the Military Technical Agreement, in which Serbia agreed on withdrawal of FRY forces and the presence of an international security force. Text available at http://edition.cnn.com/WORLD/europe/9906/09/kosovo.agreement.text/, 4 September 2017. More on the background see in Behrami and Behrami v France, Saramati v France, Germany and Norway [GC], Application Nos 71412/01 and 78166/01, Decision of 2 May 2007.
} 
subsequent accession of Serbia to the ECHR ${ }^{76}$ the issue of Serbia's obligations under the ECHR in Kosovo did not attract much attention. This was simply because no case directly involving Serbia's obligations towards people in Kosovo actually arose while Serbia's status as Kosovo's nominal sovereign remained undisputed. Serbia's sovereignty over Kosovo was confirmed by the ECtHR rather casually in the Behrami and Saramati ${ }^{77}$ case, found to be inadmissible, which concerned the conduct of other States parties that contributed to international civil (UNMIK) and security (KFOR) presences in Kosovo. ${ }^{78}$

Paradoxically, it was only after Kosovo declared independence from Serbia in February 2008 that the ECtHR was presented with an opportunity to decide on Serbia's obligations under the ECHR in Kosovo. In Azemi ${ }^{79}$ the application related to the non-execution of a municipal court judgment rendered in 2002, which ruled in favour of the applicant in a 1990 suit for unlawful termination of employment. In November 2013, the ECtHR declared the application inadmissible, ruling (as the respondent itself had argued) that Serbia lacked jurisdiction over the applicant. ${ }^{80}$

Distinguishing the position of Serbia and Kosovo from that of Moldova and Transdniestria, the Court observed that 'there [wa]s no evidence that Serbia exercised any control over UNMIK, Kosovo's judiciary or other institutions that had been established by virtue of UNMIK regulations. Neither [could] it be said that the Serbian authorities supported militarily, economically, financially or politically Kosovo's institutions. ${ }^{91}$ Noting Kosovo's declaration of independence, the number of subsequent recognitions it obtained, and the reduced role of UNMIK, the Court concluded that 'there existed objective limitations which prevented

\footnotetext{
${ }^{76}$ Serbia became bound to the ECHR in March 2004 by way of continuity with the State Union of Serbia and Montenegro, as the FRY had previously renamed itself. See more in T Papić, 'The More You Ignore Me the Closer I Get: Application of the European Court of Human Rights' Standards on the Journalistic Duty of Care in Serbia' in V Beširević (ed), Public Law in Serbia: Twenty Year After (European Public Law Organization 2012) 197.

${ }_{77}$ Behrami, paras 69-70.

${ }^{78}$ Due to their incompatibility ratione personae with the provisions of the ECHR, as the ECtHR viewed all alleged violations to be attributed to the UN, since it had, under Chapter VII of the UN Charter, authorized the international presence in Kosovo. See Behrami, paras 128-152. For analysis of the decision see M. Milanović, T. Papić,'As Bad As It Gets: The European Court of Human Rights' Behrami and Saramati Decision and General International Law' (2009) 58 ICLQ 267.

${ }^{79}$ Azemi v Serbia, Application No 11209/09, Decision of 5 November 2013. The applicant argued that this decision was based on Serbian legislation 'as inherited by UNMIK, legally defined the consequences of actions or failure to act' on the part of Serbia when it effectively exercised control over Kosovo. ibid para 37.

${ }^{80}$ ibid paras $33,49$.

${ }^{81}$ ibid paras $43,45$.
} 
Serbia from securing the rights and freedoms in Kosovo. ${ }^{82}$ Finally, the ECtHR held that the applicant did not indicate any suitable measures in respect to his rights which Serbia had the power to take, and concluded it could not point to 'any positive obligations that the respondent State had towards the applicant (compare and contrast with Moldova's positive obligations in the case of Ilaşcu [...]). ${ }^{83}$

There are many questions raised by this decision which cannot be discussed due to limited space. ${ }^{84}$ The Court's reasoning is not a model of clarity. At the outset it explicitly took a neutral position towards the status of Kosovo, in order to avoid ruling on who the sovereign of that territory actually was, ${ }^{85}$ thus implying a departure from its position in Behrami without properly justifying why it was doing so. ${ }^{86}$ It then vacillated between treating Serbia as the territorial State or as a foreign State in respect of the area. An example of the latter was the discussion on whether Serbia controlled, financed and supported Kosovo's institutions, ${ }^{87}$ by analogy to Russia in $\mathrm{Ilasscu} .{ }^{88}$ As for the former, the Court examined positive obligations and the 'objective limitations' preventing Serbia from securing the ECHR in Kosovo. ${ }^{89}$ In other words, the Court avoided ruling on Serbia's sovereignty over Kosovo (or lack thereof) by implicitly saying that even if Serbia was the sovereign, and hence had Ilaşcu-type residual positive obligations, such obligations were not relevant or were discharged on the facts of the case. The key consideration for the Court thus seemed to have been the evasion of the sovereignty issue.

As a purely pragmatic matter this approach is defensible, even if it is as matter of principle at odds with the idea that residual positive obligations follow sovereign title over territory. Namely, there are substantial differences between Kosovo and other contested territories (Northern Cyprus, Transdniestria and Nagorno-Karabakh) that were discussed by the ECtHR previously in the context of jurisdiction. Unlike the latter, Kosovo has been recognized

\footnotetext{
82 ibid para 46.

83 ibid para 47.

${ }^{84}$ For discussion of some of the issues see K Istrefi, 'Azemi v Serbia: discontinuity of Serbia's de jure jurisdiction over Kosovo' (2014) 4 European Human Rights Law Review 388; Id., 'Azemi v. Serbia in the European Court of Human Rights (Dis)continuity of Serbia's De Jure Jurisdiction over Kosovo' (EJIL: Talk!, 13 March 2014) $<$ https://www.ejiltalk.org/azemi-v-serbia-in-the-european-court-of-human-rights-discontinuity-of-serbias-de-jurejurisdiction-over-kosovo/>.

${ }_{85}$ Azemi, para 1, fn. 1.

${ }^{86}$ See also arguments offered in Istrefi (n 84) 393.

87 ibid para 45

${ }^{88}$ See text accompanying note 31 .

${ }^{89}$ Azemi, para 46.
} 
as an independent State by many States ${ }^{90}$ and its declaration of independence - effective in creating statehood or not - does not violate international law in the eyes of the ICJ. ${ }^{91}$ These facts may have warranted different conclusions on jurisdiction than those which were implied in Behrami, rendered before the declaration of independence. On the other hand, Kosovo has not been recognized by Serbia and a number of other European States, it is not a UN member or a member of the Council of Europe, and is hence unable to become a State party of the ECHR. A consequence of the Court's approach in Azemi is hence that in Kosovo there is precisely the kind of vacuum in protection of ECHR rights that it was so desperate to avoid in other cases. ${ }^{92}$

Finally, the Court's analysis of the lack of any obligations on the part of Serbia because it did not control, finance or support Kosovo institutions could in fact by applied conversely to individuals who live in ethnic Serb enclaves in Kosovo, especially in the north and the Mitrovica area, in which Serbia's influence is extensive, and might - in the right type of case - even be regarded as decisive. Serbia's influence was at its highest during the period in which it funded parallel institutions of the Kosovo Serbs. ${ }^{93}$ Consider also, for example, the recent assassination of Oliver Ivanović, a prominent moderate Serb politician in northern Kosovo - depending on the facts, one could well imagine Serbia being held to have some positive obligations under Article 2 ECHR. Serbia in fact wanted to actively participate in the Kosovo authorities' investigation of Ivanović's murder (a request which the latter rejected on sovereignty grounds), and has taken at least some investigative steps on the territory of Serbia proper in that regard. ${ }^{94} \mathrm{~A}$ suitable comparison point in existing ECtHR case law might be the 2017 Chamber judgment in Güzelyurtlu and Others v. Cyprus and Turkey, ${ }^{95}$ in which the Court found Cyprus and Turkey responsible under the procedural limb of Article 2 for failing to cooperate with each other in

\footnotetext{
${ }^{90}$ At the time of the completion of this article, it was (according to the Kosovo government) recognized by 113 states, $<$ http://www.mfa-ks.net/?page $=2,224>$. The Serbian government however disputes that some of these recognitions in fact occurred, while also claiming that some have been withdrawn.

${ }^{91}$ Due to the fact that international law did not contain a prohibition of such a declaration. ICJ, Accordance with international law of the unilateral declaration of independence in respect of Kosovo (Advisory Opinion) [2010] ICJ Rep 403, 436ff.

${ }^{92}$ See also Yudkivska (n 1), at 14.

${ }^{93}$ See more M Prelec and N Rashiti, 'Serb Integration in Kosovo After the Brussels Agreement' (Balkans Policy Research Group, 19 March 2015) < http://balkansgroup.org/wp-content/uploads/2017/09/Serb-Integration-inKosovo-After-Brussels-Agreement.pdf $>$.

${ }^{94}$ See, e.g., 'Kosovo Serb politician Oliver Ivanović shot dead outside party headquarters' (The Guardian, 16 January 2018) <https://www.theguardian.com/world/2018/jan/16/oliver-ivanovic-serb-politician-in-kosovo-shotdead $>$.

${ }^{95}$ Güzelyurtlu and Others v. Cyprus and Turkey, Application No 36925/07, Judgment of 4 April 2017.
} 
investigating a multiple homicide which occurred in Cypriot territory, whereas relevant evidence and suspects were present in Turkish and TRNC-controlled territory. ${ }^{96}$ While the Chamber was split by 5 votes to 2 on whether Cyprus had the duty to cooperate with separatist TRNC authorities (the majority essentially finding that it did), it was unanimous that Turkey had the obligation to cooperate with Cyprus, solely on the basis that the suspects were present on its territory, ${ }^{97}$ a holding difficult to square with the victim-focused case law on the jurisdiction clause in Article 1 ECHR. As of the time of writing, the case is pending before the Grand Chamber.

\section{EVALUATING THE COURT'S APPROACH}

It is, as in all matters concerning Article 1 ECHR, difficult to provide a precise descriptive account of the ECtHR's approach to the Convention's applicability in contested territories. This is primarily because the Court's approach has evolved in a very ad hoc, fact-dependent way. Initially the Commission and the Court both applied a simple, binary analysis - if the State concerned no longer had control of a part of its territory, then it no longer had jurisdiction over that area. The State will be presumed to have control over all territory over which it has title, but this is a simple evidentiary presumption which is in line with the fact that most states control most of their territory most of the time. This presumption is rebuttable, and the consequence of the rebuttal is lack of jurisdiction and therefore lack of any ECHR obligations.

The main shift in the Court's approach happens in Ilasçu, where residual positive obligations are directly tied to the state's sovereignty over the territory. Jurisdiction is thus reduced in scope in the case of loss of State control over territory, but not extinguished; it persists, if diminished, on the basis of title alone. We have seen the various difficulties that the Court has had to grapple with post-Ilasçu; another major concern is the continuing confusion

\footnotetext{
96 ibid, paras 282-297.

${ }^{97} \mathrm{ibid}$, paras 183-189. The Court examined the jurisdiction issue proprio motu, i.e. the Turkish government did not argue that the Convention did not apply extraterritorially on the facts of the case. Cf. Rantsev v. Cyprus and Russia, Application No 25965/04, Judgment of 7 January 2010, which concerned the death of a Russian woman who was trafficked to Cyprus. There the respondent government did make a jurisdictional objection, which the Court dismissed by noting that the trafficking of the victim commenced on Russian territory. ibid paras 205-208. The Court subsequently found a violation of procedural obligations on the part of Russia only in respect of the trafficking, and not in respect of the victim's death, which had occurred in Cyprus. ibid paras 243-247, 307-309.
} 
evident in the case law between the notion of jurisdiction in Article 1 and the law of state responsibility.

This brings us to the question of the normative desirability and coherence of the Court's approach. There are at least three fundamental problems with the Court's development of residual positive obligations grounded in sovereign title. First, it has no basis in the text of the Convention, and it muddles the legal nature of the concept of jurisdiction in Article 1 ECHR, undermining the basic idea that jurisdiction is a factual exercise of State power, either over territory (as in Loizidou or Chiragov) ${ }^{98}$ or over individuals (as in Al-Skeini) ${ }^{99}$ It is this factual notion of jurisdiction that has proven so important in the context of the extraterritorial application of the ECHR, and there seems to be no good reason of principle to treat intraterritorial situations any differently. ${ }^{100}$ Jurisdiction in the sense of Article 1 is either the right to exercise a power, or the actual exercise of that power, whether lawfully or unlawfully; it cannot coherently be both. And there are many good reasons to prefer the latter option, as the Court has done in the past, not the least of which is that it closes many loopholes in situations in which states interfere with human rights without exercising any kind of entitlement or authority under international law (consider everything from a full-scale unlawful invasion of a third country to the surveillance, ${ }^{101}$ abduction ${ }^{102}$ or even assassination ${ }^{103}$ of people living there).

Second, residual positive obligations bring few practical benefits; they will rarely have significant bite. Recall how the Court in Ilasçu articulated two such obligations - Moldova's obligation to take reasonable measures to re-establish its control over the contested territory, and

\footnotetext{
${ }^{98}$ Loizidou (merits), para 52: 'the responsibility of a Contracting Party could also arise when as a consequence of military action - whether lawful or unlawful - it exercises effective control of an area outside its national territory. The obligation to secure, in such an area, the rights and freedoms set out in the Convention, derives from the fact of such control (...).' Chiragov, para 168.

${ }^{99}$ Al-Skeini, paras 133-137.

${ }^{100}$ See also Milanović (n 2) 106-107.

${ }^{101}$ See, e.g., Human Rights Watch and Others v Foreign Secretary, UK Investigatory Powers Tribunal, UKIPTrib 15_165-CH, 16 May 2016, paras 49-64 (the Tribunal finding that the ECHR does not apply to UK surveillance activities abroad); M Milanović, 'Human Rights Treaties and Foreign Surveillance: Privacy in the Digital Age' (2015) 56 Harvard International Law Journal 81.

102 See, e.g., Lopez Burgos v Uruguay (1981) 68 ILR 29, UN Human Rights Committee, Communication No. R.12/52, UN doc supp no 40 (A/36/40); B Nussberger and FJ Langmack, 'A Cold War like Thriller in Summer - Icy Times Between Vietnam and Germany' (EJIL: Talk!, 20 February 2018) < https://www.ejiltalk.org/a-cold-war-likethriller-in-summer-icy-times-between-vietnam-and-germany/>.

${ }^{103}$ For example, the assassination of Alexander Litvinenko ostensibly by Russian agents in London in 2006, the 2017 killing of Kim Jong-nam at the Kuala Lumpur airport, allegedly at the orders of his half-brother, the North Korean dictator Kim Jong-un, or the attempted murder of Sergei and Yulia Skripal in Salisbury in 2018.
} 
its obligation to engage with the authorities of the contested territory so as to secure the rights of the individual applicant. ${ }^{104}$ The former issue, that of re-establishment of State control, involves so many different circumstances and is so politically contingent that it is not capable of any meaningful judicial management. Whether Moldova ever takes back control over Transdniestria, or Ukraine takes back control over Crimea or the Donbas, or Georgia takes back control over South Ossetia and Abkhazia, depends least of all on the ECHR and on anything the European Court might say. And indeed on the facts of Ilasçu the Court found that obligation discharged, employing a standard of review so deferential that it was essentially meaningless - all it took to satisfy it was for Moldova to demonstrate the desire to take back control over Transdniestria at some point in the future. ${ }^{105}$

When it comes to the more specific obligation to secure the rights of individual applicants, it may have some practical relevance, but again not hugely so. In the vast majority of cases the entity controlling the area, and thus having the actual capacity to violate or secure the applicants' rights, will be antagonistic to the central State authorities and there is only so much that the latter will be able to do. If we look at the facts of Catan, for example, in which the Court had found Moldova to have already discharged its positive obligations regarding schools in Trandniestria which wanted to use the Latin script, we will see that the actual enjoyment of the rights in question depends foremost on the separatist authorities. If the Catan judgment had any positive impact on the matter (and we do not know whether it actually did), it would be because of the Russian side of the case, as it is Russia that has decisive influence over the separatists. In short, the residual positive obligations articulated by the Court are in most instances likely to have only a marginal benefit.

The third problem with the idea of residual positive obligation grounded in title is that it logically requires the Court to pronounce on the sovereignty over the contested territory if it

\footnotetext{
104 Ilasçu, para 339.

105 ibid para 345. See also Yudkivska (n 1), at 9: '[The obligation to re-establish control] appears to be pure political rhetoric having little to do with legal obligations, and also hardly subject to assessment by legal measures. Moldova was further obliged "to refrain from supporting separatist regime." I find it rather difficult to reconcile positive obligations towards people remaining on occupied territories with the obligation to refrain from supporting the separatist regime. These obligations seem mutually exclusive - if a state engages in negotiations with separatists requesting them to secure human rights of individuals on occupied territories (that was precisely what the Court was expecting to have been done for Mr Ilascu), it follows that it would propose something in exchange, such as providing economic support they might need. If Moldova was under obligation to negotiate the release of $\mathrm{Mr}$ Ilascu and others, it had to give something to the separatists in addition to the already ceded territory.'
} 
wishes to find a violation of the residual obligation. The sovereignty question may or may not be legally straightforward, and as we have seen the Court has certainly pronounced on such issues in the past, as with respect to northern Cyprus or Transdniestria. However, as soon as that question became legally complex, as it did with regard to Kosovo and Serbia, the Court in Azemi avoided it by watering the residual obligation so much that Serbia could not have violated it even if the obligation had existed in the first place.

But the sovereignty question may be legally easy yet still politically fraught with difficulty. Consider only Crimea and the multitude of interstate and individual cases dealing with the conflict in Ukraine. One can easily imagine that the Ukrainian government would positively want the Court to affirm its continued sovereignty over Crimea, whatever the precise obligations at stake might be, whereas Russia would accept the ECHR's applicability to its own actions in Crimea but would deeply resent any adverse finding by the Court on the sovereignty question. ${ }^{106}$ We personally do not have a problem with the Court antagonizing Russia or any other powerful State - on the contrary. But is this really worth doing if it has no meaningful impact on improving the human rights of any affected individuals, and if the Court's pronouncements are used only instrumentally in a sovereignty dispute?

The Court may well find itself in an unenviable position if a factual pattern emerges which alleges violations of residual obligations on the part of Ukraine which are of similar gravity to Ilasçu, so that it could not easily pull an Azemi avoidance manoeuvre. In such a case, again, if it wishes to find a violation of the residual obligation it must also rule that Ukraine remains the sovereign of Crimea. It would not have to rule on sovereignty for any violation on the part of Russia, whose jurisdiction can simply be based on the effective control over the area, whether obtained lawfully or unlawfully. ${ }^{107}$ It is thus manifest that, although the Court's Ilasçu jurisprudence was motivated by good intentions, it carries with it significant risks. At least to our eyes, the costs would seem to clearly outweigh the benefits. And while it is unlikely that the Court would overrule Ilasçu expressly, ${ }^{108}$ it may nonetheless choose to apply it very narrowly. What, then, would be the possible alternatives?

\footnotetext{
${ }^{106}$ Russia's position would likely be different with regard to the Donbas, over which it does not claim sovereignty.

${ }^{107}$ Loizidou (merits) para 52.

108 The residual positive obligations approach was recently affirmed by 16 votes to 1 in the Grand Chamber judgment in Mozer v. the Republic of Moldova and Russia [GC], Application No 11138/10, Judgment of 23

February 2016, paras 96-112 in which the Court found no reason to depart from its conclusions in Catan. Mozer was
} 
There are, in our view, two such viable alternatives. The first is to return to the traditional binary approach - jurisdiction as a purely factual notion of territorial control, which may be presumed in territories over which the State has title. But once that presumption is rebutted, the State will no longer have jurisdiction, and therefore no positive obligations. This is the approach that we would endorse. Its principal virtue is its clarity, both regarding the factual control test and the consequences that follow. ${ }^{109}$ Once engaged, the full positive obligation to secure human rights in the area would apply. On the other hand, this approach may, in exceptional cases, be underinclusive, in the sense that there would be things that the State could do to mitigate an adverse situation for an individual, as in Ilasçu, which do not require territorial control. As we explained above, however, such situations will be rare, because the residual positive obligation as articulated by the Court has so little bite. The underinclusiveness is, in other words, offset by the clarity and manageability of the jurisdictional test, which applies in essentially the same way both intra- and extraterritorially.

The second alternative would be to apply a more functional approach, which would tie the emergence of positive obligations directly to the state's capacity to fulfil them. Such capacity would vary depending on the level of influence it exercises in any given area. Whereas the binary approach is an all-or-nothing one in terms of the applicability of positive obligations, here they would be divided and tailored depending on the circumstances. ${ }^{110}$ The basis of the obligations would not, however, be in sovereignty over the territory, but in the capacity to fulfil these obligations as a matter of fact. ${ }^{111}$ In other words, the positive obligation is not only flexible but it is not residual, since its basis is in capacity rather than in title; in particular, the Court would not need to rule in any way on a sovereignty dispute regarding the specific territory in question.

We can observe a similar approach in the Bosnian Genocide case, in which the ICJ circumscribed the positive obligation of states to prevent genocide (which it held applied even

\footnotetext{
followed by a number of Chamber judgments, the most recent of which (and somewhat unique on the facts, in that it concerned a prisoned operated by Moldovan authorities in the separatist Transnistrian territory) is Pocasovschi and Mihaila v. the Republic of Moldova and Russia, Application No 1089/09, Judgment of 29 May 2018.

109 See Milanović (n 2) 115-116, 209-228.

110 See Y Shany, 'Taking Universality Seriously: A Functional Approach to Extraterritoriality in International Human Rights Law' (2013) 7 L. and Ethics Hum. Rts. 47.

${ }^{111}$ See also N van der Have, The Prevention of Gross Human Rights Violations Under International Human Rights Law (Springer 2018) 117-120.
} 
extraterritorially) by reference to the level of State ability to fulfil it. ${ }^{112}$ Another useful analogy is to the threshold of belligerent occupation in IHL. Scholars are divided in that regard between the adherents of a more traditional, binary approach, in which occupation requires boots on the ground and exists either fully or not at all, and the advocates of a more functional approach, in which the status of occupation, and the level of obligations that flow from it, are more matters of degree than of bright lines. ${ }^{113}$ The paradigmatic example around which this debate is normally had is of course Israel's position with regard to Gaza, in which it (generally) does not have boots on the ground but over which it has a an enormous degree of influence. ${ }^{114}$

Unlike the traditional binary approach, the functional model does not suffer from concerns about underinclusiveness. The problem with the functional model, however, is that it effectively destroys jurisdiction as a preliminary threshold inquiry - positive obligations will exist whenever they should exist, in the Court's appreciation, and this is always going to be a subjective and substantive evaluation of some kind. The functional model lacks the clarity of its binary counterpart, and may lead to greater levels of disagreement on the bench about what is fitting and appropriate in any given circumstances. And, like the ECtHR's Ilasçu approach, it might still not do much in practice. Unlike Ilasçu, however, the formal basis for this model is not territorial sovereignty, which becomes an irrelevant factor in the inquiry. The Court could, in other words, take a functional approach to Ukraine's positive obligation to someone in Crimea without ruling affirmatively that Ukraine remains the sovereign of Crimea.

\footnotetext{
${ }^{112}$ Application of the Convention on the Prevention and Punishment of the Crime of Genocide (Bosnia and Herzegovina $v$ Serbia and Montenegro) (Merits) [2006] ICJ Rep 43, paras 430, 434, 438, esp. para 430: 'Various parameters operate when assessing whether a State has duly discharged the obligation concerned. The first, which varies greatly from one State to another, is clearly the capacity to influence effectively the action of persons likely to commit, or already committing, genocide. This capacity itself depends, among other things, on the geographical distance of the State concerned from the scene of the events, and on the strength of the political links, as well as links of all other kinds, between the authorities of that State and the main actors in the events.'

${ }^{113}$ See, e.g., A Gross, The Writing on the Wall: Rethinking the International Law of Occupation (CUP 2017); T Ferraro, 'Determining the Beginning and End of an Occupation under International Humanitarian Law,' (2012) 94 IRRC 133; see also M Milanović, 'The ICRC's Position on a Functional Approach to Occupation' (EJIL: Talk!, 18 November 2015), <https://www.ejiltalk.org/the-icrcs-position-on-a-functional-approach-to-occupation/>.

${ }^{114}$ See, e.g., Y Shany, 'Binary Law Meets Complex Reality: the Occupation of Gaza Debate' (2008) 41 Israel Law Review 68.
} 


\section{CONCLUSION}

The flow of cases dealing with contested territories, especially in Eastern Europe, is not going to be abating in the near-to-medium term. There is therefore an urgent need for the European Court to adopt a coherent, principled approach to such cases, ${ }^{115}$ especially because they are also related, legally, factually and politically, to situations of extraterritorial application. Post $\mathrm{Al}$ Skeini the Court's approach to extraterritorial exercises of jurisdiction in the sense of Article 1 seems to be evolving in the right (more factual, and more expansive) direction. Within contested territories, however, the Court's Ilasçu jurisprudence remains problematic. As we have seen, the whole idea of residual obligations based in sovereignty is especially challenging in situations of territorial contestation which are chronic, and in which the contestation happens between two States (as with Ukraine and Russia over Crimea) or between a State and an entity which has a legally arguable claim to statehood (as with Serbia and Kosovo). If the Court has to rule on the sovereignty claims in such cases - at is logically has to if it wishes to find a violation of the residual positive obligation - it runs the risk of provoking significant political backlash without doing much, if anything, to meaningfully advance the human rights of the individuals concerned. We do not think it wise, especially in the current political climate, for the Court to be deciding on say (the lack of) Russia's sovereignty over Crimea when it has better alternatives available, such as the binary and functional approaches we have looked at above.

This article has looked primarily at the threshold jurisdictional question. But as we have said at the outset that jurisdictional question is in reality connected with how the Convention is expected to apply on the merits. ${ }^{116}$ We have seen how flexible positive obligations can be in the context of contested territories. Such flexibility could in appropriate situations be further enhanced by taking into account other relevant areas of international law, such as IHL - e.g. in the still ongoing conflict in Eastern Ukraine. In other, stable and chronic situations of territorial contestation, as e.g. with regard to Northern Cyprus, the Court has also shown a willingness to normalize such situations somewhat ${ }^{117}$ - consider how in Demopoulos the Court required, for admissibility purposes, the exhaustion of internal remedies provided by the separatist TRNC. ${ }^{118}$

\footnotetext{
115 See also Yudkivska (n 1), 16-19.

116 See Milanović (n 2) 106-117.

${ }^{117}$ See also G Nuridzhanian, '(Non-)Recognition of De Facto Regimes in Case Law of the European Court of Human Rights: Implications for Cases Involving Crimea and Eastern Ukraine’ (EJIL: Talk!, 9 October 2017),
} 
Clearly, the experience of the ECHR with contested territories is one that other human rights bodies can draw lessons from. Our focus was solely on the ECHR, but contested territories of the kind we have examined exist all over the world, and are probably more common outside Europe than within it. Just as it is inevitable that the European Court will have to deal more extensively with such situations in the future, so will other human rights courts and treaty bodies. ${ }^{119}$ The main lesson to learn from the European experience, we think, is that good intentions do not necessarily translate to the most human rights-friendly outcomes.

Finally, we would note that the problems we have examined are by no means unique to human rights treaties. There is ongoing litigation, for example, as to how investment treaties would apply vis-à-vis Ukraine and Russia with respect to foreign investments in Crimea. ${ }^{120}$ The relevant dispute settlement mechanisms can also draw on the ECHR experience with contested territories - the fundamental dilemma (which need not be resolved in the same way in different branches of international law) is whether to primarily look at the facts on the ground or at formal considerations such as sovereignty as sources of legal obligation. At least in human rights law, our preference is strongly for the former.

$<$ https://www.ejiltalk.org/non-recognition-of-de-facto-regimes-in-case-law-of-the-european-court-of-human-rightsimplications-for-cases-involving-crimea-and-eastern-ukraine/>

${ }_{118}$ Demopoulos v Cyprus [GC], Application Nos 46113/99, 3843/02, 13751/02, 13466/03, 10200/04, 14163/04, 19993/04, 21819/04, Decision of 1 March 2010.

${ }^{119}$ The Human Rights Committee has, for example, already dealt with such a situation in respect of Crimea, as part of its monitoring and reporting function rather than through an individual communication; its concluding observations on Russia's report thus take 'due regard for General Assembly resolution 68/262 on the territorial integrity of Ukraine' - a diplomatically oblique reference to Ukraine's continued sovereignty - while Russia's obligations are predicated on its effective control over the territory. UN Human Rights Committee, 'Concluding observations on the seventh periodic report of the Russian Federation,' (2015) CCPR/C/RUS/CO/7 para 23.

${ }^{120}$ See, e.g., N Tuzheliak, 'Investors at conflict's crossroads: an overview of available international courts and tribunals in the Crimean context' (2017) 6 UCL Journal of Law and Jurisprudence 14. 